\title{
Molecular genetic evidence for the prevalence of outcrossing in the hermaphroditic brooding bryozoan Celleporella hyalina
}

\author{
K. Hoare*, R. N. Hughes, A. J. Goldson \\ Brambell Building, School of Biological Sciences, University of Wales, Bangor, Gwynedd LL57 2UW, Wales, UK
}

\begin{abstract}
The occurrence of inbreeding was investigated in Celleporella hyalina, which has been reported as being capable of selfing. In total, 4 tetranucleotide microsatellite markers were scored in populations from sites within the Menai Strait (Wales) and the Yealm Estuary (Plymouth, England). All loci in all populations were in Hardy-Weinberg equilibrium, with insignificant $F_{\text {is }}$ values, which indicates that $C$. hyalina in these populations generally outbreed. No significant differences were found between populations up to $8 \mathrm{~km}$ apart, indicating sufficient gene flow on this scale to form a single breeding population despite geographic separation. The Plymouth population was significantly $(\mathrm{p}<$ 0.00001 ) deviant from the others, indicating possible isolation by distance at the scale of $900 \mathrm{~km}$. $C$. hyalina cultured in the laboratory were observed to spawn sperm into the surrounding seawater. Sib larvae were found to settle randomly with respect to each other. In isolation C. hyalina failed to produce offspring, though a small proportion brooded abortive embryos. Painings between individuals of differing genotypes resulted in the production of offspring, all of which, when genotyped with respect to the parent colonies, were found to be the result of outcrossing.
\end{abstract}

KEY WORDS: Inbreeding · Fertilisation · Outcrossing $\cdot$ Sibs $\cdot$ Genetics · Bryozoan $\cdot$ Celleporella

\section{INTRODUCTION}

The sessile cheilostome bryozoan Celleporella hyalina is a clonal, colonial invertebrate which encrusts macroalgae in the intertidal zone. It is a simultaneous hermaphrodite with separate male, female and feeding zooids and broods its embryos in specialised ovicells. Released larvae settle within a few hours (Ryland 1974)

Many bryozoans are believed to produce viable selfed larvae (Maturo 1991). Marcus (1938) found sperm in male, female and feeding zooids of Celleporella hyalina from Brazil and suggested intracolonial sperm migration as a means of self-fertilisation. Hughes (1987) and Hunter \& Hughes (1993) state that sperm release has never been observed in C. hyalina.

\footnotetext{
- Present address: School of Ocean Sciences, University of Wales Bangor, Menai Bridge, Gwynedd LL59 5EY, Wales, UK E-majl: kh@fferal.freeserve.co.uk
}

However, $C$. hyalina is protandrous, in that male zooids are always produced before female zooids, which would indicate at least some outbreeding of all colonies, and male zooids often occur at high frequencies, which would not be expected in a purely selfing species. Hughes (1989) found variation among $C$. hyalina colonies in proportions of male and female zooids and suggested that colonies with higher proportions of male zooids may be more outbreeding while those with more females may predominantly self Hunter \& Hughes (1993) found that isolated C. hyalina, i.e. colonies cultured since settlement without exposure to exogenous sperm, could produce embryos, though no larval settlement was seen, while Yund \& McCartney (1994) claimed to have evidence for selfing in American individuals, while admitting extensive contamination. It has, therefore, been considered that inbreeding is likely to occur in C. hyalina. Self-sterility mechanisms have yet to be described for any bryozoan. 
Inbreeding has important consequences for the genetic architecture and fitness of a species (Charlesworth \& Charlesworth 1987). Reduction in fitness due to inbreeding has long been known (Darwin 1868). This fitness reduction is caused by increased homozygosity, which exposes the effects of deleterious recessive alleles and negates heterozygote overdominance. Beaumont et al. (1995) and Husband \& Schemske (1997) have provided compelling evidence that heterozygote advantage is due much more to the masking of deleterious recessives (the partial dominance theory) than to any positive enhancement of activity of a locus in heterozygotes compared to fully-functional homozygotes (the overdominance theory). However, lethal recessive alleles can be purged within very few generations of selfing, giving a fitness rebound (e.g. Saccheri et al. 1996), and inbreeding lowers the costs of sexual reproduction while conferring some of its benefits.

Some marine bryozoans have been shown to be strongly philopatric, settling very close to the maternal colony and failing to colonise or having low rates of colonisation of suitable substrate less than $1 \mathrm{~m}$ away (Keough \& Chernoff 1987, Knowlton \& Jackson 1993). Keough (1984) showed that larvae of the bryozoan Bugula neritina exhibit kin-recognition, settling preferentially near sibs. Philopatry and, perhaps consequently, inbreeding can be selected for in species which occupy temporally stable niches within a geographically diverse habitat, because they maintain adapted genotypes within a population. Philopatry and brooding can be co-selected, in that both reduce offspring mortality, particularly important in organisms in which small body size restricts the number of gametes produced. Body size is increased in Celleporella hyalina by asexual reproduction (coloniality) but is restricted both by high population density (Cancino 1986) and by the short lifespan of individual macroalgal fronds which it inhabits. Selfing can give many of the advantages of asexual reproduction while avoiding, by recombination, many of its disadvantages, such as the steady accumulation of mutations.

This study examines the prevalence of inbreeding and outbreeding in Celleporella hyalina through an investigation of the genetic structure of wild populations, through laboratory matings and through an examination of the tendency of sib larvae to settle nonrandomly with respect to each other.

\section{MATERIALS AND METHODS}

Wild populations. Celleporella hyalina were collected from Church Island, Menai Bridge $\left(53^{\circ} 13^{\prime} \mathrm{N}\right.$, $\left.4^{\circ} 10^{\prime} \mathrm{W}\right)$ and Beaumaris $\left(53^{\circ} 16^{\prime} \mathrm{N}, 4^{\circ} 05^{\prime} \mathrm{W}\right)$ in April
1996 and from the River Yealm estuary, Plymouth $\left(50^{\circ} 19^{\prime} \mathrm{N}, 4^{\circ} 02^{\prime} \mathrm{W}\right)$ in July 1997 The straight-line coastal distance between Church Island and Beaumaris is approximately $8 \mathrm{~km}$ and between Church Island and Plymouth about $900 \mathrm{~km}$. In addition, the Church Island collection was split between those collected on a single Laminaria saccharina frond and those collected from other fronds 10 and $100 \mathrm{~m}$ from the first. Although these subsample sizes were small, they permitted a preliminary assessment to be made of the scale of genetic differentiation within and among populations.

Colonies were homogenised in TE buffer plus $2 \%$ SDS, then proteinase $\mathrm{K}$ and RNase digested before precipitating proteins with ammonium acetate. Ethanol was used to precipitate DNA from the supernatant. DNA was washed, dried and resuspended in TE buffer. PCR amplifications of the 4 microsatellite markers CHY1, CHY4, CHY5 and CHY6 were as described in Hoare et al. (1998). Reactions were run out on $6 \%$ agarose gels with TBE buffer with M13 mp18 sequence reaction size standards. Gels were fixed, dried and autoradiographed and alleles scored according to their position relative to the known sizes of bands in the sequencing ladder. Agreement to HardyWeinberg expectations and population differentiation were tested using the Exact test with Levene's correction and Fisher's method, with probabilities estimated using the Markov chain method (GENEPOP, Raymond \& Rousset 1995). GENEPOP was also used to test for linkage among the scored genotypes. Both O'Connell \& Wright (1997) and Gaggiotti et al. (1999) have suggested that the infinite alleles model $F_{\mathrm{sl}}$ statistic of Wright (1965) is more conservative in practice than the stepwise mutation model based statistic $\mathrm{R}_{5 t}$ of Slatkin (1995), and therefore data were analysed using the FSTAT program of Goudet (1995).

Laboratory crosses. Ripe colonies of Celleporella hyalina collected from Beaumaris in April 1996 were induced to release larvae by dark/light stimulation (Cancino \& Hughes 1987). Larvae were allowed to settle on conditioned substrata and grown on in isolation. in $0.2 \mu \mathrm{m}$ filtered, UV sterilised seawater; C. hyalina sperm has a minimum head diameter of $0.6 \mu \mathrm{m}$ (Hughes 1987). Precautions were taken to prevent cross-contamination of culture vessels; otherwise feeding and maintenance were according to the protocol of Hunter \& Hughes (1991). Each colony was subcloned by cutting through the colony and substrate to produce fragments which were glued to new substrate, to give multiple copies of each genotype which were themselves grown on. DNA was extracted from one such clone of each genotype; the highly variable microsatellite locus CHY1 was amplified and scored as for the wild-collected specimens. Pairs of colonies were cho- 
sen so that the parentage of any offspring produced would be readily identifiable. Parent colonies of area ca $1 \mathrm{~cm}^{2}$, a realistic area for large wild colonies, were used to set up 5 crosses while clonemates of each were maintained in isolation.

Pairs were cultured together for 3 to $4 \mathrm{wk}$ then separated and placed in new containers with fresh settlement substrate for induction of larval release by dark/light stimulation. Settled larvae or ancestrulae were lysed according to a slight modification of the protocol of Corte-Real et al. (1994) and the lysate used in the amplification of microsatellite marker CHY1. These amplifications were run on sequencing gels alongside those from the parents so that parentage could be unambiguously assigned.

Larval settlement. Three families of full sib larvae produced as described above were allowed to settle on pieces of conditioned substrate held in aerated 21 culture vessels. Two replicate pieces of substrate, $30 \mathrm{~cm}^{2}$ each, were used for each family. While settlement distances were constrained by the dimensions of the culture vessels used, in nature Celleporella hyalina larvae settle at such high densities that kin dispersed over larger scales would be amidst many unrelated colonies and unlikely to inbreed together. Since Ryland (1959) has shown that larvae settle preferentially in sheltered areas the $2 \mathrm{~cm}$ wide strip of settlement substrate nearest the holding clip was neglected. The sheets were then divided into $1 \mathrm{~cm}^{2}$ squares and the number of larvae in each square counted. The dispersal index $I$, also known as the coefficient of dispersion, (Sokal \& Rohlf 1981), was used to assess whether the sibs were significantly aggregated or dispersed.

\section{RESULTS}

During the course of this investigation many Celleporella hyalina colonies were observed to release sperm from the central, longest, tentacle of male zooids. Such free release of sperm provides the opportunity for cross-fertilisation.
Table 1. Allele frequencies and $F_{\text {st }}$ values per locus for populations of Celle porella hyalina. Asterisks indicate significant $F_{s t}$ values $(" \mathrm{p}<0.05, \cdots p \leq 0.01$, $\cdots p<0.005$ ) $n=$ number of alleles scored. The Church Island population was split between those collected from a single Laminaria saccharina frond and those collected from other fronds 10 and $100 \mathrm{~m}$ from the first

\begin{tabular}{|c|c|c|c|c|c|c|c|}
\hline $\begin{array}{l}\text { Locus } \\
\text { Allele }\end{array}$ & $\begin{array}{c}\text { Church } \\
\text { Island } \\
x\end{array}$ & $\begin{array}{l}\text { Church } \\
\text { Island } \\
x+10 m\end{array}$ & $\begin{array}{l}\text { Church } \\
\text { Island } \\
x+100 \mathrm{~m}\end{array}$ & $\begin{array}{l}\text { Church } \\
\text { Island } \\
\text { Pooled }\end{array}$ & $\begin{array}{l}\text { Beau- } \\
\text { maris }\end{array}$ & $\begin{array}{l}\text { Ply- } \\
\text { mouth }\end{array}$ & $F_{\mathrm{st}}$ \\
\hline $\mathrm{n}$ & 14 & 16 & 14 & 44 & 38 & 20 & \\
\hline \multicolumn{8}{|l|}{ CHYI } \\
\hline 136 & 0 & 0 & 0.07 & 0.02 & 0 & 0 & \\
\hline 140 & 0 & 0 & 0.07 & 0.02 & 0.08 & 0 & \\
\hline 144 & 0 & 0 & 0 & 0 & 0.03 & 0.25 & \\
\hline 158 & 0 & 0 & 0 & 0 & 0 & 0.05 & \\
\hline 162 & 0.07 & 0 & 0 & 0.02 & 0 & 0 & \\
\hline 170 & 0.07 & 0 & 0 & 0.02 & 0 & 0.05 & \\
\hline 174 & 0 & 0.06 & 0.07 & 0.05 & 0 & 0 & \\
\hline 178 & 0 & 0.06 & 0 & 0.02 & 0.05 & 0 & \\
\hline 182 & 0.07 & 0.19 & 0.29 & 0.18 & 0.11 & 0 & \\
\hline 186 & 0.07 & 0.31 & 0.07 & 0.16 & 0.08 & 0.10 & \\
\hline 190 & 0.07 & 0 & 0.07 & 0.05 & 0.11 & 0.10 & \\
\hline 194 & 0.14 & 0 & 0.07 & 0.07 & 0.08 & 0.15 & \\
\hline 198 & 0 & 0.06 & 0 & 0.02 & 0.03 & 0.15 & \\
\hline 202 & 0.07 & 0 & 0 & 0.02 & 0.05 & 0.05 & \\
\hline 206 & 0.07 & 0 & 0 & 0.02 & 0.03 & 0 & \\
\hline 210 & 0.07 & 0.06 & 0 & 0.05 & 0 & 0.05 & \\
\hline 214 & 0 & 0 & 0 & 0 & 0.03 & 0 & \\
\hline 222 & 0 & 0 & 0 & 0 & 0.03 & 0 & \\
\hline 226 & 0.21 & 0.06 & 0.07 & 0.11 & 0.11 & 0 & \\
\hline 230 & 0 & 0 & 0 & 0 & 0.05 & 0 & \\
\hline 234 & 0 & 0 & 0 & 0 & 0.03 & 0 & \\
\hline 238 & 0.07 & 0.13 & 0.14 & 0.11 & 0.05 & 0 & \\
\hline 242 & 0 & 0 & 0 & 0 & 0.05 & 0 & \\
\hline 246 & 0 & 0 & 0.07 & 0.02 & 0 & 0 & \\
\hline 286 & 0 & 0.06 & 0 & 0.02 & 0.03 & 0 & \\
\hline 318 & 0 & 0 & 0 & 0 & 0 & 0.05 & \\
\hline \multicolumn{8}{|l|}{$\mathrm{CHY} 4$} \\
\hline 185 & 0.75 & 0.83 & 0.38 & 0.69 & 0.82 & 0.81 & \\
\hline 201 & 0.08 & 0 & 0.25 & 0.09 & 0.05 & 0.13 & \\
\hline 205 & 0.17 & 0.17 & 0.38 & 0.22 & 0.13 & 0.06 & 0 \\
\hline \multicolumn{8}{|l|}{ CHYS } \\
\hline 157 & 0.86 & 1 & 1 & 0.95 & 1 & 1 & \\
\hline 161 & 0.14 & 0 & 0 & 0.05 & 0 & 0 & $012 \cdots$ \\
\hline \multicolumn{8}{|l|}{ CHY6 } \\
\hline 155 & 0 & 0 & 0 & 0 & 0.08 & 0 & \\
\hline 159 & 0 & 0 & 0 & 0 & 0.03 & 0 & \\
\hline 177 & 0.93 & 0.81 & 0.93 & 0.89 & 0.76 & 0.30 & \\
\hline \multirow[t]{2}{*}{189} & 0.07 & 0.19 & 0.07 & 0.11 & 0.13 & 0.70 & \\
\hline & & & & & & & $0.26 \cdots$ \\
\hline
\end{tabular}

\section{Wild populations}

Allele frequencies and $F_{\mathrm{st}}$ values are given in Table 1. Every locus in every population was in Hardy-Weinberg equilibrium ( $p>0.1)$; Fisher's test showed that the probability of agreement to expected genotype frequencies overall was $p=0.9998$.

There was no significant genotype disequilibrium detected, therefore each is confirmed as being an independent character. 
Table 2. Genotypes of Celleporella hyalina parents and their offspring at the CHY 1 microsatellite locus. Offspring genotypes indicate that all were the result of outcrossing rather than selfing. In most trials all possible outcross genotypes were found

\begin{tabular}{|c|c|c|c|c|c|c|c|}
\hline \multirow{2}{*}{$\begin{array}{l}\text { Family } \\
1\end{array}$} & \multicolumn{2}{|c|}{ Parent genotypes } & \multicolumn{4}{|c|}{$\begin{array}{c}\text { Genotypes of offspring } \\
\text { [no. of each] }\end{array}$} & \multirow{2}{*}{$\begin{array}{c}\begin{array}{c}\text { No. of } \\
\text { offspring } \\
\text { scored }\end{array} \\
8\end{array}$} \\
\hline & $182 / 222$ & $190 / 238$ & $\begin{array}{c}182 / 190 \\
{[4]}\end{array}$ & $\begin{array}{c}182 / 238 \\
{[2]}\end{array}$ & $\begin{array}{c}190 / 222 \\
{[1]}\end{array}$ & $\begin{array}{c}222 / 238 \\
{[1]}\end{array}$ & \\
\hline 2 & $190 / 226$ & $140 / 178$ & $\begin{array}{c}140 / 190 \\
{[2]}\end{array}$ & $\begin{array}{c}140 / 226 \\
{[2]}\end{array}$ & $\begin{array}{c}178 / 190 \\
{[2]}\end{array}$ & $\begin{array}{c}178 / 226 \\
{[0]}\end{array}$ & 6 \\
\hline 3 & $140 / 226$ & $238 / 242$ & $\begin{array}{c}140 / 238 \\
{[4]}\end{array}$ & $\begin{array}{c}140 / 242 \\
{[5]}\end{array}$ & $\begin{array}{c}226 / 238 \\
{[5]}\end{array}$ & $\begin{array}{c}226 / 242 \\
{[5]}\end{array}$ & 19 \\
\hline 4 & $190 / 238$ & $140 / 202$ & $\begin{array}{c}140 / 190 \\
{[1]}\end{array}$ & $\begin{array}{c}190 / 202 \\
{[0]}\end{array}$ & $\begin{array}{c}140 / 238 \\
{[2]}\end{array}$ & $\begin{array}{c}202 / 238 \\
{[3]}\end{array}$ & 6 \\
\hline 5 & $140 / 178$ & $144 / 234$ & $\begin{array}{c}140 / 144 \\
{[2]}\end{array}$ & $\begin{array}{c}140 / 234 \\
{[3]}\end{array}$ & $\begin{array}{c}144 / 178 \\
{[5]}\end{array}$ & $\begin{array}{c}178 / 234 \\
{[1]}\end{array}$ & 11 \\
\hline Total & & & & & & & 50 \\
\hline
\end{tabular}

There were no significant differences in allele frequencies among the Church Island populations or between Church Island and the Beaumaris population at any individual locus or overall $(p>0.1)$. The Menai Strait populations, pooled or separate, differed significantly from the Plymouth population at loci CHY1 and CHY6 at $p<0.03$ and $p<0.00001$ respectively, while loci CHY4 and CHY5 showed no significant differences. Overall, the probability that the Menai Strait and Plymouth populations are genetically identical is less than 0.00001 .

Since genotype frequencies are in agreement with Hardy-Weinberg equilibrium, the calculated $F_{i s}$ is not significantly different from zero for any locus or overall, but $F_{\mathrm{si}}$, and hence $F_{\mathrm{il}}$, do have significant $(\mathrm{p}=0.01$ and $\mathrm{p}<0.005$ ) overall values, 0.083 and 0.095 , respectively, mainly due to locus CHY6. FSTAT gives a significant value of $F_{\mathrm{sl}}$ for CHY 5 because 1 site within the Church Island population has an allele that was not found elsewhere. The Exact Test shows that this locus does not differ significantly between sites within Church Island $(p>0.19)$ nor between Church Island and the other populations $(p>0.99)$. F-statistics thus show no evidence for significant inbreeding within populations, while the significant $F_{11}$ reflects the Wahlund effect due to allele frequency differences between the Menai Strait and Plymouth populations.

\section{Laboratory crosses}

Over 60 genotypes of Celleporella hyalina, including clones of those used in the setting up of mating pairs, were maintained in isolation in the laboratory as single colonies or groups of clonemates, over many months. All produced both male and female zooids. There was no settlement of offspring in any of these cultures. In total, 3 isolated genotypes were observed to brood what were assumed to be embryos, but these were aborted or resorbed before reaching the size of mature embryos. None of these 3 were used for the crosses. The first embryos appeared in the ovicells of the experimental pairs 4 to $6 \mathrm{~d}$ after pairing. Both individuals of each cross brooded and released embryos, and therefore both parents provided both eggs and sperm.

A total of 50 offspring from the 5 experimental pairings were genotyped (Table 2). All were found to be the result of cross-fertilisation. There was no evidence of either selfing or contamination.

These results demonstrate that there is either a clear preference for allosperm or that selfed offspring do not survive to settlement. The presence of another, conspecific, individual appears to be required for reproduction; the presence of such an individual does not remove any barrier to selfing since approximately equal concentrations of self sperm as allosperm must have been available without resulting in a detectable proportion of successfully settling offspring.

\section{Larval settlement}

Dispersal indices are shown in Table 3. All indicate that the distribution of settled individuals is random. Sibs therefore neither prefer to settle together nor avoid doing so.

Table 3. Dispersal indices (I) of settled Celleporella hyalina sibs. None are significantly different from 1, indicating random distribution. n: number of individuals upon which $I$ is based

\begin{tabular}{|cccc|}
\hline Family & Replicate & $\mathrm{n}$ & $I$ \\
\hline 1 & $\mathrm{a}$ & 23 & 1.124 \\
\multirow{2}{*}{2} & $\mathrm{~b}$ & 22 & 0.766 \\
& $\mathrm{a}$ & 6 & 1.357 \\
3 & $\mathrm{~b}$ & 2 & 0.947 \\
& $\mathrm{a}$ & 28 & 1.257 \\
Overall & $\mathrm{b}$ & 10 & 0.737 \\
\hline
\end{tabular}




\section{DISCUSSION}

All populations are in Hardy-Weinberg equilibrium, suggesting that inbreeding occurs at low frequencies if at all. This is supported by the observations that selfed offspring are not produced in isolation and were not detectable in laboratory crosses. The fact that a small proportion of colonies do brood abortive embryos in isolation is in agreement with the observations of Hunter \& Hughes (1993). Yund \& McCartney (1994) claimed to have evidence for selfing in American individuals, while admitting extensive contamination, whereas Cancino et al. (1991a) found that Chilean individuals did not even produce female zooids when in isolation. It is possible that there is variation in the selfing ability of Celleporella hyalina from different areas, since there is morphological and genetic evidence that they may in fact be different species (Goldson 1998, Hoare et al. 1998, K. Hoare unpubl. data). The major advantage of outbreeding is the production and maintenance of variability; our laboratory-cultured colonies - even colonies derived from the same population, cultured under the same conditionsshowed noticeable variety in colouring, colony morphology, speed of recovery from damage, proportions of different zooid types and growth rates (K. Hoare pers. obs.).

There appears to be a single, though patchily distributed, genetically homogeneous Menai Strait population of Celleporella hyalina. The Menai Strait population is significantly different from the Plymouth population, indicating that while gene flow is sufficient to homogenise over an $8 \mathrm{~km}$ stretch of coastline it is not great over the several hundred kilometres between Church Island and the Yealm estuary.

In a species in which the adult is sessile, it is reasonable to assume that dispersal is accomplished by gametes and larvae. Where embryos are brooded and the larval stage is short, as in Celleporella hyalina, dispersal would be expected to be restricted, with possible promotion of inbreeding through small effective population size. Isolation by distance has indeed been shown in brooders relative to broadcasters in some species (e.g. solitary corals, Hellberg 1996). However, Jackson (1986) found no correlation between length of larval life and geographic range for many clonal marine invertebrates. Watts et al. (1998) found that, for cheilostome bryozoans, rafting and fouling were far more important dispersal mechanisms than larval motility. It is not known how far C. hyalina populations can travel on storm-severed algal fronds or other flotsam and jetsam, but Helmuth et al. (1994) showed that the subantarctic, sessile, brooding bivalve Gaimardia trapesina could disperse over thousands of kilometres by kelp-rafting. Peterson (1996) found that in the sedentary butterfly Euphilotes enoptes such chronic low-level long-distance dispersal or occasional mass dispersal events were less important than steppingstone gene flow, which appeared to be a homogenising influence over immense distances. Prevailing currents do not necessarily restrict bryozoan dispersal; Abelson (1997) showed that Membranipora membranacea larvae can very effectively move upstream and indeed preferentially do so. Data on the brooding bryozoans Cryptosula pallasiana and Schizoporella unicornis in Watts (1997) show that replicate samples within sites are as genetically divergent as samples from widely separated sites in Britain, indicating no isolation by distance except between the east and west coasts. Direct measurements of the dispersal distances of sperm and larvae are not available for many species, but indirect evidence from genetic studies indicates that gene flow in sessile species can be sufficient to prevent population subdivision over surprisingly great distances. However, there are exceptions: Grosberg (1987) showed that larvae of the ascidian Botryllus schlosseri settle within a metre of their mother and show outbreeding depression if mated with individuals only a few metres away.

Cancino (1986) showed that Celleporella hyalina colonies naturally occur at very high densities with 70 to $100 \%$ actually coming into contact with other individuals. Such very high densities would act to promote outcrossing. Harvell \& Helling (1993) found that contact between colonies of Membranipora membranacea promotes reproductive activity in the contacting region. The Welsh form of $C$. hyalina produces male zooids at any part of the edge of a colony where growth is balked, whether contacting another colony, a physical barrier, or even another edge of the same colony $(\mathrm{K}$. Hoare pers. obs.). Reproductive activity at the site of contact with another individual promotes outcrossing but may be purely the result of a source-sink energy flow when growth is checked.

Keough (1984) showed that larvae of the bryozoan Bugula neritina exhibit kin-recognition, settling preferentially near sibs. No such kin-recognition was evident in our study of Celleporella hyalina. Cancino et al. (1991b) showed that larval release in C. hyalina is induced by dawn; such synchronous release of larvae from many colonies, in the absence of kin-recognition, will promote the settlement of mixed populations and hence outbreeding.

If dispersal is achieved largely by the rafting of perhaps dozens or hundreds of broading colonies on a piece of kelp, as is suggested by Jackson (1986) and Watts et al. (1998), then the ability to closely inbreed would not be a requirement for founding a new population since it is likely that any founding event would involve relatively large numbers of individuals. 
Husband \& Schemske (1996) found that, in plants, inbreeding depression increases through life in routinely selfing species compared to routine outcrossers, because strongly deleterious alleles affect seed production and so are swiftly purged, but less deleterious alleles affecting growth and reproduction are more refractory. The chance fixation of deleterious alleles can permanently reduce fitness in selfing species (e.g. Carr \& Dudash 1997). Disruption of overdominance may also play a part in chronic inbreeding depression.

The ability to self-fertilise is widely taken as one of the principal advantages of hermaphroditism, but in sessile brooding animals in a space-limited habitat hermaphroditism can confer optimal reproductive fitness even without the capacity to self. Hermaphroditism avoids much of the cost of sex, since male function can be a relatively energy-inexpensive by-product of a brooding colony. In addition, young colonies can produce sperm before they are energetically capable of brooding, colonies may have more energy available for reproduction than they have space available in which to brood, and in uncertain or unfavourable conditions reproductive output can be switched to the male function. It could even be argued that hermaphrodites are less inbred than dioecious species; in dioecious species there is never truly random mixing of the gene pool, since individuals of the same sex cannot mate.

Bishop (1996) showed that the compound ascidian Diplosoma Listerianum is largely able to prevent selfing by trapping and destroying self sperm in the oviduct. Any selfed embryos are aborted (Bishop \& Ryland 1991). Bishop \& Ryland (1991) demonstrated sperm storage in D. listerianum. Mated Celleporella hyalina colonies continue to produce outcrossed offspring when returned to isolation for over 2 mo, longer than the gestation period of 3 to $4 \mathrm{wk}$ ( $\mathrm{K}$. Hoare pers. obs.). This indicates that there must be some form of sperm storage which would act to promote outbreeding. It is tempting to speculate that there must be a similar arrangement in C. hyalina to that which Bishop (1996) and Bishop \& Ryland (1991) have demonstrated in D. Listerianum.

Acknowledgements. We thank the Leverhulme Trust for funding this work. Dr John Bishop kindly suppled us with Celleporella hyalina from Plymouth

\section{LITERATURE CITED}

A.belson A. (1997) Settlement in flow: upstream exploration of substrata by weakly swimming larvae. Ecology 78: $160-166$

Beaumont AR, Fairbrother JE, Hoare K (1995) Multi-locus heterozygosity and size: a test of hypotheses using triploid Mytilus edulis. Heredity 75:256-266
Bishop JDD (1996) Female control of paternity in the internally fertilizing compound ascidian Diplosoma listerianum. I. Autoradiographic investigation of sperm movements in the female reproductive tract. Proc R Soc Lond B 263:369-376

Bishop JDD, Ryland JS (1991) Storage of exogenous sperm by the compound ascidian Diplosoma listerianum. Mar Biol 108:111-118

Cancino JM (1986) Marine macroalgae as a substratum for sessile invertebrates: a study of Celleporella hyalina (bryozoa) on fronds of Laminaria saccharina (phaeophyta). Monogr Biol 4:279-308

Cancino JM. Hughes RN (1987) The effect of water flow on growth and reproduction of Celleporella hyalina (L.) (Bryozoa, Cheilostomata). J Exp Mar Biol Ecol 112:109-130

Cancino JM, Castaneda B, Orellana MC (1991a) Reproductive strategies in bryozoans: experimental test of the effects of conspecific neighbours. In: Bigey FP (ed) Bryozoaires actuels et fossiles. Bull Soc Sci Nat Ouest Fr Mém HS1, p 81-88

Cancino JM, Hughes RN, Ramirez C (1991b) Environmental cues and the phasing of larval release in the bryozoan Celleporella hyalina (L.). Proc R Soc Lond B 246:36-45

Carr DE, Dudash MR (1997) The effects of five generations of enforced selfing on potential male and female function in Mimulus guttatus. Evolution 51:1797-1807

Charlesworth D, Charlesworth B (1987) Inbreeding depression and its evolutionary consequences. Annu Rev E.col Syst 18:237-268

Côrte-Real HBSM, Holland PWH, Dixon DR (1994) Inheritance of a nuclear DNA polymorphism assayed in single bivalve larvae. Mar Biol 120:415-420

Darwin CR (1868) Variation of animals and plants under domestication. John Murray, London

Gaggiotti OE, Lange O, Rassmann K, Gliddon CJ (1999) A comparison of two indirect methods for estimating average levels of gene flow using microsatellite data. Mol Ecol 8:1513-1520

Goldson AJ (1998) Genetic and phenotypic variation in two marine bryozoans. PhD thesis, University of Wales, Bangor

Goudet J (1995) FSTAT version 1.2. A computer program to calculate F-statistics. J Hered 86:485-486

Grosberg RK (1987) Limited dispersal and proximity-dependent mating success in the colonial ascidian Botryllus schlosseri. Evolution 41:372-384

Harvell CD, Helling $R$ (1993) Experimental induction of localised reproduction in a marine bryozoan. Biol Bull 184: 286-295

Hellberg ME (1996) Dependence of gene flow on geographic distance in two solitary corals with different larval dispersal capabilities. Evolution 50:1167-1175

Helmuth B, Veit RR, Holberton R (1994) Long-distance dispersal of a subantarctic brooding bivalve (Gaimardia trapesina) by kelp-rafting. Mar Biol 120:421-426

Hoare K, Hughes RN, Gliddon CJ (1998) Polymorphic microsatellite markers isolated from the bryozoan Celleporella hyalina (L.). Mol Ecol 7:355-356

Hughes DJ (1987) Gametogenesis and embryonic brooding in the cheilostome bryozoan Celleporella hyalina. J Zool (Lond) 212:691-711

Hughes DJ (1989) Variation in reproductive strategy among clones of the bryozoan Celleporella hyalina. Ecol Monogr $59: 387-403$

Hunter E, Hughes RN (1991) Growth of laboratory cultured colonies of Celleporella hyalina (L.). In: FP Bigey (ed) Bryozoaires actuels et fossiles. Bull Soc Sci Nat Ouest Fr Mém HS1, p 187-191 
Hunter E, Hughes RN (1993) Self-fertilisation in Celleporella hyalina. Mar Biol 115:495-500

Husband BC, Schemske DW (1996) Evolution of the magnitude and timing of inbreeding depression in plants. Evolution 50:54-70

Husband BC, Schemske DW (1997) The effect of inbreeding in diploid and tetraploid populations of Epilobium angus. tifolium (Onagraceae): implications for the genetic basis of inbreeding depression. Evolution 51:737-746

Jackson JBC (1986) Modes of dispersal of clonal benthic invertebrates: consequences for species' distributions and genetic structure of local populations. Bull Mar Sci 39: $588-606$

Keough MJ (1984) Kin recognition and the spatial distribution of Jarvae of the bryozoan Bugula neritina (L.). Evolution 38:142-147

Keough MJ, Chernoff H (1987) Dispersal and population variation in the bryozoan Bugula neritina. Ecology 68:199-210

Know]ton N, Jackson JBC (1993) Inbreeding and outbreeding in marine invertebrates. In: Thornhill NW (ed) The natural history of inbreeding and outbreeding: theoretical and empirical perspectives. University of Chicago Press, Chicago, p 200-249

Marcus E (1938) Bryozoarios marinhos Brasileiros II. Bol Fac Fil Cienc Letr Univ Sao Paulo. Ser Zool 2:1-196

Maturo FJ (1991) Self fertilisation in gymnolaemate bryozoa. In: FP Bigey (ed) Bryozoaires actuels et fossiles. Bull Soc Sci Nat Ouest Fr Mém HS1, p 72 (appendix)

O'Connell M, Wright JM (1997) Microsatellite DNA in fishes Rev Fish Biol Fish 7:331-363

Peterson MA (1996) Long-distance gene flow in the sedentary butterfly Euphilotes enoptes (Lepidoptera, Lycaenidae). Evolution 50:1990-1999

Editonal responsibility: Otto Kinne (Editor),

Oldendorf/Luhe, Germany
Raymond $M$, Rousset $F$ (1995) GENEPOP (version 1.2): population genetics software for exact tests and ecumenicism. J Hered 86:248-249

Ryland JS (1959) Experiments on the selection of algal substrates by polyzoan larvae. J Exp Biol 36:613-631

Ryland JS (1974) Behaviour, settlement and metamorphosis of bryozoan larvae: a review. Thalassia Jugosl 10:239-262

Saccheri IJ, Brakefield PM. Nichols RA (1996) Severe inbreeding depression and rapid fitness rebound in the butterfly Bicyclus anynana (Satyridae). Evolution 50: $2000-2013$

Slatkin M (1995) A measure of population subdivision based on microsatellite allele frequencies. Genetics 139:457-462

Sokal RR, Rohlf FJ (1981) Biometry - the principles and practice of statistics in biological research, 2 nd edn. WH Freeman \& Co, New York

Swofford DL, Selander RB (1981) BIOSYS-1: a FORTRAN pro gram for the comprehensive analysis of electrophoretic data in population genetics and systematics. $J$ Hered 72 : 281-283

Watts PC (1997) Population genetic and biogeographic consequences of dispersal in cheilostome Bryozoa. PhD thesis, University of Liverpool

Watts PC, Thorpe JP, Taylor PD (1998) Natural and anthropogenic dispersal mechanisms in the marine environment a study using cheilostome Bryozoa. Phil Trans R Soc Lond B 353:453-464

Wright $S$ (1965) The interpretation of population structure by $F$-statistics with special regard to systems of mating. Evolution 19:395-420

Yund PO, McCartney MA (1994) Male reproductive success in sessile invertebrates - competition for fertilisations. Ecology 75:2151-2167

Submitted: February 3, 1999; Accepted: May 28, 1999

Proofs received from author(s): October 14, 1999 